\begin{tabular}{lll}
\hline VOL. IV & MAY, 1895 & No. 5 \\
\hline
\end{tabular}

\title{
SUGGESTIONS ON THE ORGANIZATION OF CORPORATIONS.
}

Having regard to their creation, there have been three principal eras of private corporations. During the first period they were created by royal prerogative. These franchises were generally granted as royal favors. They were more or less related to the administration of public affairs or the increase of the material interests of the home government or its colonies. The purpose of their creation was largely to extend the political power or increase the revenues of the Crown. The essential characteristics of such corporations were only two, perpetuity and exclusive rights. The directors or managers constituted the corporation. Stockholders, as the term is now used, were then unknown. Their existence was not contemplated in the deed or grant of incorporation. Their rights, duties and liabilities were not defined. They were shareholders only in the limited sense that they had the right to share the profits earned by the stockholders or managers. The foundation of this right lay in contract only. Their relation to the directors was that of trustee and cestai qui trust. As a general rule they could not even select their own directors, the right to fill vacancies in that body being vested in the remaining members of the board.

The second period is that in which, both in this country and in England, corporations were created by legislative enactment. Each corporation was created by a separate enactment. The most general plan of creation was to constitute certain persons named, as incorporators or commissioners, authorizing them to receive subscriptions for the capital to be applied to the undertaking named in the enactment. When a given amount of capital was thus subscribed they were directed to call the subscribers together, and the latter perfected their organization by electing: their officers and directors and defining their respective duties by by-laws adopted by them. Thus the stockholders have come 
prominently into view. Their power in the organization and management of the corporation is increased; that of the directors is diminished and defined. The stockholders select the directors, define their duties and limit the duration and scope of their offices.

The public was not as yet quite prepared for the idea that he, for whose benefit the common undertaking is carried on and who derives all the resulting profits therefrom, should enjoy absolute immunity from the common law liability of joint undertakers. Therefore a conservative compromise between general, individual liability on the one hand and entire immunity from the claims of creditors on the other, was hit upon, and it was generally provided that the individual liability of the stockholder for the debts of the corporation should bear a limited, fixed relation to the amount of stock held by him. This liability has been defined to be secondary, the creditor being first required to pursue the corporation to the extent of its assets. This idea is preserved in our national bank statutes, whereby the stockholder is made individually liable in an amount equal to the stock held by him. It is in most of the charters of our State banks, and in some States, as in Ohio, it applies to all private corporations. The prominent characteristics of corporations of this era, as contrasted with the preceding one are perpetuity, power of the stockholders over the management of the company and limited liability of the stockholders.

As these corporations were created by an act of the legislative body, politics often dominated its action both in granting and withholding franchises. Strong lobbies grew up at our capitals, whose business it was to procure valuable franchises and sell them to others. The more liberal the scope of the charter, the greater the immunity of the stockholder, the more valuable the franchise was to sell. So broad and unlimited became the scope of these franchises, that they were properly called "omnibus" charters. One such might be instanced under which a steamship line was operated on the Atlantic seaboard; it was next used as the contractor to construct an interstate railway in the Southwest; now it is used to supply a large city with gas. Naturally this nefarious traffic in public franchises worked its own destruction; took from our legislature the power to grant franchises, and produced the third era of corporate creation which may be called the "Free Corporation Era."

England has not entered into this era as completely as our States have. There the right still resides in Parliament to create certain corporations, such as railway companies. In all of the 
States of our Union and as to almost all kinds of corporations, the right to become a corporation is free to any of its citizens, voluntarily associating themselves together for such purpose.

The evident purpose sought to be secured by these free corporation statutes, was to encourage opposition in manufacture and commerce and to prevent monopoly. With few exceptions, there is no liability on the part of the stockholders beyond paying for the stock for which they have subscribed. This done, the company can borrow money, increase its liabilities to any extent it can procure credit, run itself into hopeless bankruptcy, and the stockholders enjoy absolute immunity from the claims of creditors. In many States there is absolutely nothing to prevent unlimited "watering of capital stock." In a few States ten per centum of the capital stock must be paid in cash. Even with this requirement, the organizers of the proposed corporation can subscribe for one-tenth of the capital and pay that in full in cash, and there their individual liability ceases. They can then issue to themselves the remaining nine-tenths of the capital stock "fully paid up" in consideration for untried patent rights, or for other property at enormously inflated value.

The capital stock being thus paid, may be then made the foundation for further corporate dishonesty and false credit. Again referring to the corporation statutes of our various States, we find that in most of them, these corporations can issue bonds for an amount equal to their paid-up capital stock. Thus a property, which is not worth and would not sell for one thousand dollars, is made the basis of ten thousand dollars of credit, simply because certain incorporators are by law permitted to issue to themselves, paid-up stock in excess of the true value of the property for which the stock was issued. In addition to all this are the general liabilities, the floating indebtedness of the company. If such a corporation be successful, the stockholder has realized on his watered stock; if unsuccessful, the stockholder has lost only one-tenth of the money invested-the creditor loses the balance. The latter then has the lean choice of taking upon his shoulders an enterprise which never should have been begun, or allowing it to go through ruinous liquidation. The risk of the venture is almost entirely on the creditor; the profit, if any, goes to the stockholder. This is an extreme, but not an uncommon example. It simply carries out the evil of our present corporate system to its ultimate results, and illustrates its tendency. The large number of corporate stocks now selling on our exchanges below par, prove to what extent they do not represent actual value. Recently, a judge of our federal. 
courts was called upon to appoint a receiver of a certain railroad. A newspaper article, announcing this fact the next morning, stated that it had been expected that the road would be open for traffic within a month, but the appointment of a receiver mayr delay this. Poor thing, it had died at its birth. Most probably its parents did not lose much; the creditors had built it.

- Looking at the present condition of the markets for our corporate securities, we may see that the striking characteristics of the corporations of our third era are protection to the stockholder, risk to the creditor. The reason for this is not hard to find when we consider the manner in which many of our corporate enterprises have been organized.

But how remedy this? The national bank system of governmental inspection and valuation of assets and compulsory liquidation or repairment of capital by assessment upon stockholders, in case of impairment of capital, will perhaps be thought too inquisitorial and paternal for these times. We would therefore suggest the following, not so drastic, but largely efficacious.

First, Permit capital stock to be issued only for cash, and only to the amount of cash actually paid by the stockholders. Thus, capital stock will mean what it pretends to be, so much money invested in the corporate enterprise.

Second, Make the stockholder individually liable to creditors for the amount, at least, equal to the stock held by him. As stated above, courts have construed this liability to be secondary to the primary liability of the corporation itself.

Third, Prohibit the directors from issuing bonds, debentures or other fixed forms of indebtedness, without the consent of the majority of the stockholders. If stockholders are individually liable, even to a limited extent, they will not lightly consent to the company's borrowing money it cannot reasonably expect to pay, nor will they long suffer with a directory whose management is running the company into bankruptcy, and them into individual liability.

Reorganization plans, reorganization committees of bankrupt companies are heard of on every hand. The plan invariably is to cut down the capital stock to something like its real value, or assess the stockholders, to give the stock an intrinsic value. Why not do this when the corporation is organized, and give to corporate stocks and bonds a just and honest basis of value? The times demand a remedy: Our legislators should provide, one.

Willis F. McCook.

Pittsburgh, PA. 